\title{
THE THEOLOGY OF THE INCARNATION: A PARADIGM FOR A THEOLOGY OF CONTEXTUAL IN THE ERA OF THE THIRD MILLENNIUM
}

\author{
Ranto \\ Efrata Evangelical Theology College - Sidoarjo \\ E-mail: rantoasmaredja@gmail.com
}

\begin{abstract}
Why is it necessary to learn the Theology of the Incarnation, it is not separated from some of the advantages of basic and very critical of the approach of this theology. First, the Theology of the Incarnation to take the role as a theology of contextual provided the Bible itself, and that God has taken this pattern in the states themselves, and his word to man. This is the pattern and the case of biblical theology and contextual theology in the context of health. Next, as an example the case of theology is contextual, the role of the incarnation embodies well the demands of the two mandates the basis of theology is contextual. In this case, God and His Word are eternal it is final, eternal, and unchangeable in the encounter, and 'incarnation" in humanity and human culture. While at the same time, there is no doubt that it is relevant and following the bible.
\end{abstract}

Keywords: Theology, Incarnation, following the bible, biblical

\section{INTRODUCTION}

Looking at the development of theology in today's world, especially entering the third millennium, there is a growing movement of theology with attention to the very large to context, and along with its demands greater will be the relevance to the context. If within a few decades ago contextualization seems to be a concern in the theology in the third world (with the culture of the local), now the

challenge of theology contextual taking the context of human life in the broadest sense, such as science, medical, economic, social, cultural, political, gender, nature, technology, philosophy, mysticism, psychology, and so on. In addition, the challenges of the context of this wrapped in the ideology of 
relativism, postmodernism, pluralism, as well as the dynamics and acceleration of the changes in various fields.

As a result, today there is the fact that theology into fragments that are fragmentary and sporadic, which are scattered everywhere, as the fruits of the dialectic and the reflection in the issues of political, cultural, economic, social, gender, psychology, and various other fields. There are many causes of the development of theology today, which is indeed on the one side seemed relevant in certain fields, but are not intact, the subjective and stereotypes, and not infrequently less balanced in referring to the whole truth of scripture.

Symptoms then looked where-where is "theology" as a form of reaction and the formulation of the theological-pragmatic less consider the entity of the nature of theology as a whole and thorough. In this state, the discussion of theology about the society or the social context and of the church with the dynamics of the real on the earth immediately bring to the dialectic between the text of scripture in the realm of the ideal-normative and the realm of the context in the broadest sense. Actually, this issue is not new in the world of theology.

However, as the development of the third millennium, especially with the dynamics of the context that is so fast and complex, the struggle will theology vitalnormative and contextual in the dynamics of the context of the third millennium be one of the theological issues most important today.

On the other hand, the reality and the challenges this can not be denied and requires serious attention because of its important role, especially concerning the problem of praxis that is engrossing in a framework of theology healthy, but relevant to the challenges and struggles of the contemporary context, where the authority and the authority of scripture is at stake in the practice of life post-modern.

It takes a concept and paradigm of theology and theology of a healthy and dynamic, which refers to mandate basic theology Theocentris, sourced and the starting point for a normative-dogmatic on the finality of the revelation of God, any God-oriented. However, referring to the reality of the revelation of God is articulated through cultural and human context at that time, then theology also has the mandate to dynamic contextual, relevant, dynamic and actual, in the lives of believers, in the context of the actual now. In other words, the call of theology bears the mandate to theology in the normative-contextual.

Starting from all the facts and the above considerations, as well as referring to the model of the dialectic of God himself 
when visualizing the word in the context of dynamic and relevant, then the writer is compelled to struggle a paradigm of theology and theology is intact, normative at once contextual (relevant to the context), namely "the Theology of the Incarnation". Different forms of theology contextual scattered sporadically so far, the Theology of the Incarnation is meant as a paradigm of the ideal-normative intact and holistic, so it's not a kind of theology of the situation patterned pragmatic. This paradigm is expected to provide improvements fundamental weaknesses substantially from the tendency of theology in the third millennium, such as situation, relative, stereo if, the subjective, the pragmatic, and so on, on the one hand; and on the other side of the stiffness formulation of the theology of the century-the last century is supreme but not longer relevant.

\section{RESEARCH METHOD}

This research is library research (library research). What's called the research literature or often also called literature, is a series of activities concerning data collection method literature, reading and note-taking as well as the processing of materials research. [1]

In this study, the authors apply the method of the research literature because there are at least some of the reasons underlying it. The first is that the source data is not always can be obtained from the field. Sometimes the source of the data can only be obtained from the library or other documents in the form of writing, both of journal, books, and literature of the other.[2]

\section{RESULTS AND DISCUSSION}

This section will address the discussion around the identification and definition of the Theology of the Incarnation, the following scope of understanding, and the things associated with the understanding of the Theology of the Incarnation. It is intended since the beginning to provide a discourse conceptual as identifies the right to use the technical term is.

In addition, this discussion is also important to avoid misunderstanding theology about it, and especially also to lay down the runway and the reference paradigm for the form/formulation of theology that will be developed in the patron that philosophy. The study in this chapter will be discussing: understanding theology, the nature of theology, the definition of incarnation, the understanding of the Theology of the Incarnation. 


\section{Understanding The Incarnation,}

\section{According To The Bible}

Better a noun "incarnation" or the words are not found in the Bible. But the equivalent Greek word for the Latin

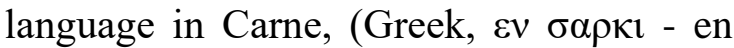
sarki) are on some important statements in the NT about the person and work of Jesus Christ.[3] The hymns quoted in 1 Timothy 3:16 here called ' $\mathrm{He}$, who has revealed himself in the flesh': "And without controversy great is the mystery of godliness: God was manifested in the flesh (Inkarnasi), Justified in the Spirit, Seen by angels, Preached among the Gentiles, Believed on in the world, Received up in glory".

"Et manifeste magnum est pietatis sacramentum quod manifestatum est in carne (Inkarnasi) iustificatum est in spiritu apparuit angelis praedicatum est gentibus creditum est in mundo adsumptum est in

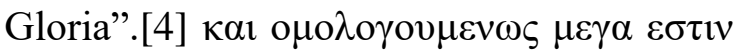

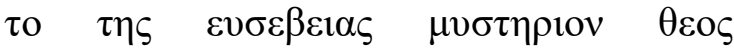
$\varepsilon \varphi \alpha v \varepsilon \rho \omega \theta \eta \varepsilon v \sigma \alpha \rho \kappa \iota \varepsilon \delta \iota \kappa \alpha \iota \omega \theta \eta \varepsilon v \pi v \varepsilon v \mu \alpha \tau \imath$ $\omega \varphi \theta \eta \quad \alpha \gamma \gamma \varepsilon \lambda \mathrm{or} \varsigma \quad \varepsilon \kappa \eta \rho v \chi \theta \eta \quad \varepsilon v \quad \varepsilon \theta v \varepsilon \sigma \mathrm{lv}$ $\varepsilon \pi \iota \sigma \tau \varepsilon v \theta \eta \varepsilon v \kappa о \sigma \mu \omega \alpha v \varepsilon \lambda \eta \varphi \theta \eta \varepsilon v \delta o \xi \eta[5]$

The translation of each word in the interlinear is as follows:

kai \{as for\} homologoumenôs \{that should be recognised (anyone) $\}$ mega \{large $\}$ estin $\{$ is $\}$ to tês $\{($ it $)\}$ eusebeias \{worship\} mustêrion $\{$ secret: $\}$ theos $\{$ God \} ephanerôthê $\{\mathrm{He}$ was $\}$ en $\{$ in $\}$ sarki \{meat\} edikaiôthê \{proved to be true /released $\}$ en $\{$ by [in] $\}$ pneumati $\{$ the Spirit (Holy ghost)/ the Spirit of His,\} ôphthê \{seen\} aggelois $\{$ by angels, $\}$ ekêrukhthê \{reported\} en \{between $\}$ ethnesin $\{$ the nations (gentiles), $\}$ episteuthê $\{$ trusted $\}$ en \{in $\}$ kosmô $\{$ world $\}$ anelêphthê $\{$ lifted $\}$ en \{in/ with\} doxê \{glory.\}[6] LAI translates "He who has revealed himself in the likeness of a human", whereas manuscripts Textus Receptus write ' $\theta \varepsilon \circ \varsigma \varepsilon \varphi \alpha v \varepsilon \rho \omega \theta \eta \varepsilon v$

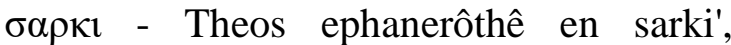
literally: "God - He declared - in - flesh".

This was stated by John in the introduction to his Gospel: 'the Word' (the perpetrators of God in creation, that 'in the beginning', before the creation of not only 'together with God', but also 'is God', John 1:1-3) 'being human' (sarx=flesh) John $1: 14$. Then in the context of the incarnation, Christ the everlasting God, then taking the form of "be a man" (Philippians 2; Jn.1:14), and on the same time, He is still God.

$\mathrm{He}$ is the eternal God, from eternity, and never stop as the eternal God in his perfect it. Authorization and finality to God-ness is not displaced or terreduksi, or uninstalled because of His humanity. So He died as a man that is of eternal and also continuous is God. 
The events of the incarnation of Christ

So, the truth about the incarnation should be formulated is, that God, without ceasing to be God, also to be human.

\section{The Theology Of The Incarnation}

In the standard and the level of identification of technical terms in the discussion of this Journal, and refers to a form of theology that is relevant in the era of the third millennium now, the "Theology of the Incarnation" refers to the notion that identifies as the formulation of theology and theology is contextual-biblical in the era of the third millennium this". What is meant by "contextual-biblical" in this case is not only as a "trademark" of theology but rather refers to the demands of accountability designed in realizing the two mandates of the theology of the.

Business meets the formulation of theology and theology "contextual-biblical" this will then be realized by taking the patron principle-the principle of the incarnation of Christ as a frame of reference and the paradigm of theology in the context of millennium three. This is what is meant by "the Theology of the Incarnation", namely the formulation of theology and theology is contextual and biblical in the era of the third millennium is concerning the philosophy and paradigm of the incarnation of Christ. as the embodiment of the theology of contextual authentic and biblical at the same time teach as well as the stated about how the nature of news (i.e. the revelation of the self and god's word) is to be understood. At a time when The Word, who is God became a man (or take the way in humanity actually), He does not cease to be God and does not reduce the essence of himself when expressed itself in the context of humanity.

Reduced in all the essence of the fulness of the God-ness when to be human and express themselves in the context of humans. Therefore the Bible says about Him incarnate that "all the fullness of the Godhead dwells in him".

The incarnation has led to the revelation of God and him that dynamics and dimensions of context in such a way, nevertheless the fact of the incarnation affirms that if the core news that is fixed and eternal, in its fullness that is not degraded in the context. This confirms that based on the philosophy, the theology of the incarnation theology is contextual is essential "the revelation and preaching of the news of the eternal" in the context. So, instead of a form and a business encounter the text and context of the meeting point together.

The incarnation of Christ is a moment contextual, and indeed take the dynamics of the local specific, such as Jewish culture, 
Hebrew, Aramaic, Greek, the political situation and the history and traditions of the Jews, and so on. It is sometimes causes misunderstanding in some circles, whereas if the truth of the incarnation is a product of local Jews at that time so that the doubt of the meaning of normative-theoretical; or as if it is only "the truth locative" just Jewish.

If observing John.1:1-18 and Philippians 2, it was evident that the issue of the basis of its contextual does not necessarily draw on the issue of location and social situation of its historical course, but of the eternal God reveals himself in humanity. The context of the local Jews especially should be viewed in relation to far back on the Old Covenant that is rooted in the covenant of God and Abraham is the forerunner of the Jewish nation. In this context and in the context of the Nation of the Jews, the covenant of salvation advanced gradually to reach the peak of their fulfillment in the incarnation of Christ, death, and resurrection. The context is the main history of the salvation of God so that the context of local Jews in the incarnation should be viewed in the corridors of the covenant of God.

\section{CONCLUSION}

Amid the swift pace of change and the dynamics of the context that is so complex and fast, and at the same time accompanied by the rise of the revival of contemporary theology as well as the spirit of theology in context, some challenges will be a formulation of the theology and theology authentic at once relevant to this era. Namely the era of the third millennium. In the spirit of such, in general, the main issues are concentrated at the two poles, namely the demands of faithfulness to the text of the Word of God the final; and on the other side of the demands are so strong will be of relevance with the context of the real.

Travel theology and theology in contemporary history have shown the failure here and there, which concerns the substance of the two poles of the above, and appears as the extreme right and the extreme left. Reflecting on the lessons of travel theology throughout history and refers to the Incarnation of Christ as the example of the theology of contextual authentic, biblical, and relevant, then the Theology of the Incarnation that adopts the framework of the concept and paradigm of the incarnation of Christ become one of the choices for theology that is relevant in the era of the third millennium this.

In summary, the Theology of the Incarnation paid great attention to carrying 
out and realizing the demands that refer to mandate basic theology Theocentris, sourced and the starting point for a normative-dogmatic on the finality of the revelation of God, any God-oriented. However, referring to the reality of the revelation of God is articulated through cultural and human context at that time, then theology also has the mandate to dynamic contextual, relevant, dynamic and actual, in the lives of believers, in the context of the actual now. In other words, the call of theology bears the mandate to theology in the normative-contextual.

\section{REFERENCES}

[1].Mestika Zed, The Methods of Literature Research, Obor Indonesia, Jakarta, 2008,

[2].http://eprints.stainkudus.ac.id/851/6/BA B\%20III.pdf

[3]. J. D. Douglas (Ed.), Encyclopedia of the Bible Today Volume 1: A-L, (Jakarta: Yayasan Komunikasi Bina Kasih/OMF, 1992)

[4]. Bible translation the Latin Vulgate

[5]. Bible translations of the Greek Textus Receptus

[6]. Hasan Sutanto, Interlinear GreekIndonesia, (Malang: Southeast Asia Bible Seminary, 2002)

[7]. Ambang Pintu Teologi, Jakarta: BPK Gunung Mulia
[8].Hadiwijono, Harun, Teologi Reformatoris Abad ke-20, Jakarta: BPK Gunung Mulia,

[9]. Lumintang, Stevri Indra, Theologia DanMisiologia Reformed, Malang: Yayasan Persekutuan Pekabaran Injil Indonesia.

[10]. Leith, John H., Introduction To The Reformed Tradition, Atlanata: John Knox Press.

[11]. Ryrie, Charles C., Teologi Dasar Jilid 1, Yogyakarta: Yayasan ANDI

[12]. Douglas, J. D. (Ed.), Ensiklopedi Alkitab Masa Kini Jilid 1: A-L, Jakarta: Yayasan Komunikasi Bina Kasih/OMF [13]Sutanto, Hasan, Interlinear YunaniIndonesia, Malang: Seminari Alkitab Asia Tenggara [14]. Tomatala, Yakub, Teologi Kontekstualisasi: Suatu Pengantar, Malang: Penerbit Gandum Mas Hasselgrave, David J. dan Rommen, Edward, 